\title{
KNOWLEDGE MANAGEMENT IN A COMPANY
}

\author{
Petrică Stoica \\ Court of Accounts Bacău \\ petricastoica@yahoo.com \\ Ovidiu Leonard Turcu \\ "Vasile Alecsandri" University of Bacău \\ t_ovidiu@softhome.net
}

\begin{abstract}
All organisations are primarily interested in maintaining and increasing intellectual capital assets, and knowledge management represents only a manner of supporting the satisfaction of this interest and of laying stress on this type of assets. A mistaken conception, according to which at the level of a company there is a finite knowledge store that can be "managed", reflects nothing but the fact that, at the beginning, many companies have overlooked the general aim of their business. The intangible part is immaterial, difficult to describe, quantify and measure. The intangible asset has and creates value and that is why the evaluation of intellectual property does not represent a simple activity. From a modern viewpoint, organisational learning does not consist only in obtaining new knowledge, but also considers its employment in carrying out the activities of the company, and so it contributes to the generation of new knowledge. The success of companies depends on the personnel's ability to understand, manipulate and develop information. In case of epistemic economy, the improvement of the innovation capacity, the creation of value and wealth are based on the division of knowledge.
\end{abstract}

\section{Keywords}

business; knowledge; companies; management; economy

\section{JEL Classification}

O10; M10

In specialised literature, knowledge management represents the conceptualization of a company as an integrated system of knowing and leading a company so that knowledge can be used in actual fact.

The first Romanian study related to knowledge management was published by Ştefan Iancu, who emphasized the ideas of intellectual capital and economic organisation.

In relation to knowledge, management is viewed in two ways:

- as management of the company, a case in which it is concerned with the use and integration of various types of knowledge;

- the management of knowledge as such.

A possible definition of knowledge management could be the similarity with a subject which promotes an integrated approach with the aim of identifying, managing and dividing all the informational assets of a company. (Apetroae M., 2004.)

Informational assets consist in databases, documents, policies and procedures as forms of expertise and experience at the level of individual members of the organisation.

In 2001, the audit and consultancy company KPMG defined knowledge management as follows: "Knowledge management is a collective designation for a group of 
processes and practices employed by organisations in order to improve their market value, by augmenting the efficiency of generating and employing intellectual capital”. Intellectual capital must not be confused with knowledge management.

All organisations are primarily interested in maintaining and increasing intellectual capital assets, and knowledge management represents only a manner of supporting the satisfaction of this interest and of laying stress on this type of assets.

Knowledge management is a process that takes place within a company, while intellectual capital has implications which cover the entire range of operations undertaken by the company.

According to certain opinions, knowledge cannot be administered, whereas the culture that leads to the division of that knowledge can be managed.

This statement is partly true in case of tacit knowledge, which is not codified and cannot be stored; due to these reasons, tacit knowledge management represents perhaps the most difficult component of the general management of knowledge.

In a company, knowledge can be stored partially by means of a set of managerial and technological procedures and subsequently stored in adequate forms and locations, or promoted by way of internal communication networks.

However, another part will maintain its residual, tacit character, continuing to exist only in the conscience of the employees or in the interpersonal relationships they establish.

The term "worker in the field of knowledge" ("knowledge worker") was coined by Peter Drucker (Drucker P., 1999.), a management theoretician, whose prediction consequently proved to be well-grounded, thus anticipating the transformation of knowledge in an essential economic resource.

A mistaken conception, according to which at the level of a company there is a finite knowledge store that can be "managed", reflects nothing but the fact that, at the beginning, many companies have overlooked the general aim of their business.

The knowledge society represents a new economy in which the capacity to assimilate and convert new knowledge in order to create new services and products has become predominant. In the knowledge society, innovation seeks to improve productivity, not only the classical one in relation to work and capital, but also new productivity in connection with natural energy and material resources or environment protection. That is why a new economy involves encouraging the creation and development of innovative companies, which have their own knowledge structure.

Certain authors defined the difference between the old/traditional and the new economy as follows: in the old economy tangible goods count, whereas in the new economy intangible assets matter because they create value.

The intangible part is immaterial, difficult to describe, quantify and measure. The intangible asset has and creates value and that is why the evaluation of intellectual property does not represent a simple activity.

Knowledge society is a fundamental necessity in order to ensure a sustainable society from an ecological viewpoint because in the absence of scientific knowledge and technological knowledge as well as their management it will be impossible to produce goods or the technological organisations and transformations which are necessary for laying the basis of progress in the twenty first century.

As a result, the value of knowledge assets can significantly exceed the value of tangible assets.

At the global level, the store of knowledge increases much faster than it did in the past. 
A decreased level of dependence on classical resources takes place in conjunction with the amplification of this knowledge store, and knowledge gradually becomes central, as the leading capital of the firm.

The knowledge-based economy represents a new economy, which is totally different from the type of industrial economy.

The basis for carrying out change processes is represented by the transformation of the company in an organisation that learns.

Roger E. Bohn's definition of learning is useful from this perspective: "Learning is evolution of knowledge over time" (Bohn, 1998.). The transformation of a company in an organisation which learns is a process that is not begun or performed spontaneously. It is for the top management of the company to decide whether the status of "learning company" is a strategic target for it or not.

From a modern viewpoint, organisational learning does not consist only in obtaining new knowledge, but also considers its employment in carrying out the activities of the company, and so it contributes to the generation of new knowledge.

Organisational learning must be conceived in all its complexity and a learning company involves, first of all, the existence of employees who learn. Consequently, each employee must attempt to possess a type of thinking and behaviour which is centred on learning.

The key-elements are intensive communication at the level of employees in the firm and their strong motivation to obtain, protect and integrate knowledge into the organisation.

The main objective of knowledge management refers to the fact that it allows organisations to permanently improve their knowledge and become organisations that learn.

Most economic theories emphasize the identification, formalization, memorization and employment of already existing knowledge, without paying attention to the identification of the manner in which new knowledge is created within companies. The generation of economic knowledge or other types of knowledge must be attributed mainly to individuals because companies cannot create knowledge in the absence of the human factor, and it is their mission to encourage creative individuals, thus producing the proper context for the creation of knowledge.

At the level of a company, the creation of knowledge must be seen as a process of amplifying the knowledge created by individuals and of crystallizing that knowledge as a part of the explicit knowledge base of the organisation.

A company is an organic unity and plays an important role in a knowledge-based economy because it is the place where information is produced and used.

The success of companies depends on the personnel's ability to understand, manipulate and develop information.

The revolution in the field of information technology brought forth various possibilities to codify information, the cost of transmitting it becoming progressively lower (for instance, e-commerce and e-business).

Due to the information possessed by the personnel in order to make best use of its potential, the importance of teamwork and job sharing will increase.

Many corporations have implemented programmes for the dissemination of knowledge and information between two subsidiaries, and the stimulation of the innovation process takes place by means of training and lifelong education courses. In case of international knowledge transfer, communication between the subsidiaries of the same firm bears special significance.

In the organisational environment, knowledge is the result of transforming information into the ability to perform efficient action, by means of integrative 
assimilation and understanding, followed by operationalization in given contexts. Knowledge can be recorded in the brains of an individual or stored in organisational processes, products, facilities, systems or documents.

Drucker (1998) briefly describes the historical and cultural approaches to knowledge, comparing Socrates' "self-knowledge” philosophy with Protagoras' view, according to which knowledge represents "the ability to know what to say and how to say it well”.

Drucker considers that the latter interpretation has dominated, until recently, the western learning system. It views the current knowledge concept as knowledge "proved in practice" and focused on results.

In the traditional economy of an industrial type the roots of productivity boosts and of the creation of surplus value and wealth are found in the division of labour, together with specialized work.

In case of epistemic economy, the improvement of the innovation capacity, the creation of value and wealth are based on the division of knowledge.

The phrase "division of knowledge" refers to a complex process, which belongs to large interactional social groups by means of which knowledge is generated and employed efficiently.

The division of knowledge involves both the specialization and differentiation of knowledge, as well as the process of dividing or integrating knowledge domains, by means of which it is used for solving various problems.

The notion of "intellectual capital" is associated with the transformation of knowledge in something that has value - in other words, in intellectual "material", which is formalized and intensified in order to add value to it.

In their activity, companies construct representations about their own knowledge. They deal with the challenge of finding ways to make good use of what they know, although, paradoxically, they are not totally aware of what they know, or of what they do not know. "Man can neither seek what he knows, nor what he doesn't know. He cannot seek what he knows because he knows; he cannot seek what he doesn't know because he doesn't know what to look for" (Socrates).

From this perspective, the statement made by Lewis Platt, former CEO of HewlettPackard, is also significant: "If Hewlett-Packard were more aware of what it knows, we could become three times more profitable".

The foundation of the organisations' activities and those of their actors on knowledge makes the delimitation between the theoretical and applied aspects remain purely conventional in the domains associated with this evolution (knowledge management, organisational learning, and intelligent systems).

The American and West-European vision, which takes shape in organisational environments with predominantly individualistic values, places the dissemination and use of knowledge first; on the contrary, the Japanese view focuses on the production of knowledge, its dissemination being implicit in a traditional environment that is much centred on group values.

The knowledge based economy, which includes today even the SMEs from Romania, alongside with other types of organizations, puts a great emphasis on the exploitation of the intellectual capital. Each country, company and individual depends increasingly more on knowledge, which materializes in: patents, skills, technologies, and customer information about suppliers. At the level of SMEs, the technology and the associated processes act on the individual knowledge, and especially on the side of the intellectual tacit component. The management and the leadership are a powerful integrator in the nonlinear segment. The leadership is important by its power to act on knowledge, on the intelligence and on the individual values. The organizational vision 
and mission are also interesting integrators, which act mainly on the individual emotional intelligence. The organizational culture appears as a powerful integrator, since it acts mainly on the individual intelligence and on the values, creating models of the organizational behavior (Mironescu R. at al. 2013)

In conclusion a series of companies from different economic and cultural areas have transformed their ordinary activity in a research environment but also in a learning one, as suggested by the new concepts of "knowledge centre" or "corporate university”.

Significant achievements, especially at the level of new solutions for knowledge management, have been obtained in case of firms that produce both intellectual goods and intellectual-intensive goods. Among the most convincing examples we can quote the cases of companies like Ernst \& Young, Microsoft or Bucknan Laboratories, Ericsson.

We can also add those from the category of public institutions, such as the governmental authorities from Scandinavian countries, which have implemented the system of negotiated economy based on the values of social consensus and professionalism.

As a general rule, the promotion of these developments adhere to the principles of the knowledge society by applying selectively the system of public intellectual good (with free access), which has become informational content for virtual communities.

\section{References}

Apetroae, Marin (2004), Capitalul intelectual şi economiile epistemice, OPINFO, Bucureşti.

Barney, J. B. (1986), Strategic Factor Markets: Expectation, Luck and Business Strategy, Management Science, 32(10) Oct., 1231-1241.

Barney, J. B. (1991), Firm Resources and Sustained Competitive Advantage, Journal of Management, 17/1.

Barney, J.B. (1996), The Resource-based Theory of the Firm, Organization Science, 7(5) (September-October), 469-476.

Bohn, Roger E. (1998), Measuring and Managing Technological Knowledge, in Dale Neef a. o. , Eds., The Economic Impact of Knowledge, Butterworth-Heinemann, Boston, 295314

Brătianu, C. (2005b), Schimbarea de paradigmă în managementul universitar românesc, Revista de Management şi Inginerie Economică, 4(3), 7-23.

Brătianu, C. (2006), Un model de analiză a capitalului intelectual organizaţional, Management \& Marketing, 1(3), 17-32.

Brătianu, C. (2008), Leadership and management in the transition romanian higher education system, Management \& Marketing, 4(2), 21-36.

Brătianu, C., Jianu I. (2007), The vision and mission of the university. Case study, Management \& Marketing, 4(2), 37-46.

Brătianu, C., Vasilache S. (2009), Evaluating linear-nonlinear thinking style. For knowledge management education, Management \& Marketing, 4(3), 3-18.

Drucker, P. (1999), Knowledge Management in California, Management Review, 41(2).

Drucker, P. (1999), Societatea postcapitalistă, Image.

Drucker, P. (2001), Organizaţiile viitorului, Teora.

Feraru A. (2009), The concept of knowledge and knowledge the management in the Romanian business field, Studies and Scientific Researches - Economic Edition, 14, 137-141.

Feraru A. (2011), Knowledge management within organisations, Annals of the Oradea University. Fascicle of Management and Technological Engineering, IX (XIX), 1, 157160. 
Fox, T., Ward, H., Howard, B. (2002), Public Sector Roles in strenghthening corporate social responsibility, A baseline study, World Bank, October, p. 1-5.

Kelleher, D., Levene, S. (2001), Knowledge Management: A Guide to Good Practice, PWC, New York.

Kim, C., Manborgue, R. (2003), Fair Process: Managing in Knowledge Economy, Motivation People, 1.

Mironescu R., Feraru A., Drob C. (2013), Particular Aspects in the Intellectual Capital Management of the Romanian SMEs, Proceedings of the 5th European Conference on Intellectual Capital, 1, 593.

Nonaka, I., Takeuchi, H. (1995), The Knowledge Creating Company: How Japanese Companies Create the Dynamics of Innovation. Oxford University Press, New York.

Petrash G. (2002) , Knowledge Management. Classic and Contemporary works, Masschusetts Institute of Tehnology.

Roşca Ion Gh., Păunescu C., Pârvan C. (2010), Shaping the future of higher education in Romania: Challenges and driving factors, Management \& Marketing, 5(1), 57-70.

Scârneci Florentina, (2011), Who are the romanian managers and how they identify themselves?, Management \& Marketing, 6(1).

Stolojan, Theodor (2002), Demitizarea tranziţiei romaneşti, paper presented at Simpec conference, Braşov, 17-18 May 2002. 